\title{
COMPUTED TOMOGRAPHY-GUIDED CUTTING NEEDLE BIOPSY OF PULMONARY LESIONS
}

\author{
Liao Shin Yu, Daniel Deheinzelin, Riad N. Younes and Rubens Chojniak
}

RHCFAP/3063

\begin{abstract}
YU LS et al. - Computed tomography - guided cutting needle biopsy of pulmonary lesions. Rev. Hosp. Clin. Fac. Med. S. Paulo
\end{abstract} 57(1):15-18, 2002.

PURPOSE: To report the experience of a radiology department in the use of computed tomography - guided cutting needle biopsy of pulmonary nodules, by evaluating diagnostic yield and incidence of complications.

METHODS: This is a retrospective analysis of 52 consecutive patients who underwent lung lesion biopsy guided by computed tomography, performed between May 1997 and May 2000. Thirty-five patients were male and 17 were female, with ages ranging from 5 to 85 years (median, 62 years). The size of the lesions ranged from 1.8 to $15 \mathrm{~cm}$ (median, $5.4 \mathrm{~cm}$ ).

RESULTS: In a total of 52 biopsies of lung lesions, 51 biopsies (98.1\%) supplied appropriate material for histopathological diagnosis, with 9 diagnosed (17.3\%) as benign and 42 (80.8\%) as malignant lesions. Specific diagnosis was obtained in 44 (84.6\%) biopsies: 4 benign $(9.1 \%)$ and $40(90.9 \%)$ malignant lesions. The sensitivity, specificity, and accuracy of the cutting needle biopsies for determining presence of malignancy were $96.8 \%, 100 \%$, and $97.2 \%$, respectively. Complications occurred in 9 cases (17.3\%), including 6 cases $(11.5 \%)$ of small pneumothorax, 1 (1.9\%) of hemoptysis, 1 (1.9\%) of pulmonary hematoma, and 1 (1.9\%) of thoracic wall hematoma. All had spontaneous resolution. There were no complications requiring subsequent intervention.

CONCLUSION: The high sensitivity and specificity of the method and the low rate of complications have established cutting needle biopsy as an efficient and safe tool for the diagnosis of lung lesions. In our hospital, cutting needle biopsy is considered a reliable procedure for the evaluation of indeterminate pulmonary nodules.

DESCRIPTORS: Lung neoplasms. Tomography, computed axial. Needle biopsy.

The use of computed tomography (CT)-guided fine-needle aspiration biopsy has been widely used with high accuracy as reported for diagnosis of lung lesions, especially carcinomas ${ }^{1}$. On the other hand, for non-carcinomatous lesions, the accuracy of the method is inferior, reported in the range of $46 \%$ to $68 \% \%^{2-4}$. Difficulties in diagnosing benign lesions and the unavailability of a cytopathologist in the radiology department have mandated the need to perform biopsies that could supply material for histological analysis. Several successful experiences with core biopsy using automated cutting needles in several solid organs ${ }^{3}$ encouraged the use of the same method in lung lesions ${ }^{5-8}$. Previous studies reported sensitivity, specificity, and complication rate of this procedure ${ }^{5-8}$. All authors concurred that this technique produces appropriate material for diagnosis with a high accuracy rate and acceptable incidence of complications ${ }^{5-8}$.

Despite being a well-established method, the application of CT-guided needle biopsy among radiologists in our country is still not common. Few

From the Department of Radiology and Thoracic Surgery of Hospital do Câncer A. C. Camargo and "Universidade Paulista" (UNIP). national studies have reported transthoracic biopsy experience, and no specific emphasis has been made regarding the cutting needle ${ }^{9-10}$. The objective of the present study is to present the initial experience of a radiology department in the use of the cutting needle biopsy of pulmonary nodules, by evaluating diagnostic yield and incidence of complications.

\section{MATERIALS AND METHODS}

This report is a retrospective analysis of 52 consecutive patients who underwent lung lesion biopsy guided by CT using a cutting needle, performed 
between May 1997 and May 2000. Written informed consent was obtained from all patients. Thirty-five patients were male and 17 were female, with ages ranging from 5 to 85 years (median, 62 years). The size of the 52 lung lesions ranged from 1.8 to $15 \mathrm{~cm}$ (median, $5.4 \mathrm{~cm}$ ).

We used a CT Pace (GE-General Electric) scanner to locate the lesion and to guide the needle introduction. Patients were positioned to allow more direct access to the lesion, minimizing passage by aerated lung tissue to reduce the risk of pneumothorax. The needle introduction site was selected and localized on the patient by placing an external metallic marker. An automated 18-gauge cutting needle (MD Tech Tru-Core ${ }^{\circledR}$ ) was used in 40 cases, and an automated coaxial 20-gauge cutting needle with a 19-gauge introductory cannula system (Temno Biopsy needle and introductory cannula) was used in 12 cases. Local anesthesia with $1 \%$ lidocaine was applied from the skin to the pleura following the planned biopsy pathway. The needle was then introduced with the patient in expiratory apnea, and new CT scans were obtained to check the position of the needle in relation to the lesion. When the 18-gauge needle was used, it was introduced directly into the lesion. The automatic gun was then connected and fired to advance the needle cutting edge for 13 or $20 \mathrm{~mm}$, depending on the lesion size. With the coaxial system, the introducer stylet-outer cannula combination was positioned at the margin of the lesion and confirmed with CT scans. The introducer stylet was removed from the outer cannula, and the cutting needle was inserted into the outer cannula and fired, with an advance of $20 \mathrm{~mm}$ of the needle's cutting edge. The biopsy site could be visualized by $\mathrm{CT}$ control. In both situations, the procedure was repeated until the samples were macroscopically appropriate or pneumothorax was present. The fragments were preserved in $10 \%$ formalin and submitted for histopathological examination by staff of the pathology department of our institution.

After the biopsy, all patients had control CT scans to evaluate for presence of complications.

\section{RESULTS}

In a total of 52 biopsies of lung lesions, 51 biopsies (98.1\%) supplied appropriate material for histopathological diagnosis, with 9 diagnosed $(17.3 \%)$ as benign lesions and 42 $(80.8 \%)$ as malignant. Specific diagnosis was obtained in 44 (84.6\%) biopsies: 4 benign $(9.1 \%)$ and $40(90.9 \%)$ malignant lesions (Table 1).

In the group of malignant lesions, there were 26 bronchogenic carcinomas, 11 metastases, 2 cases of lymphoma, 1 mesothelioma, and 2 cases with malignant diagnosis of no specified type. Among the bronchogenic carcinomas, 20 cases were non-small cell carcinomas ( 8 cases of adenocarcinoma and 12 cases of squamous cell carcinoma), 2 cases were small cell carcinomas, and in 4 cases the carcinoma type was not specified. Eleven metastatic lesions including 9 carcinomas, 1 fibrosarcoma, and 1 osteosarcoma were identified (Table 2).

Diagnostic confirmation was possible in 36 cases, by surgery in 9 , and by clinical follow-up in 27 cases. In these patients, the diagnoses provided by biopsy were considered as definitive, and a therapeutic regimen was established. In malignant cases, the patients under- went chemotherapy or radiotherapy. Two benign cases were confirmed clinically; one case with chronic inflammation had complete radiological image resolution, and the other case with fibrosis had radiological image stability and was clinically asymptomatic for 2 years. The definitive diagnoses included $31(86.1 \%)$ malignancies and 5 (13.9\%) of benign disease (Table 2). In 15 cases, diagnostic confirmation was not possible because these patients were no longer being treated at our institution.

From the 5 cases of benign lesions without specific diagnosis on needle biopsy, definitive histology was obtained by surgery in 4: 1 granuloma, 1 inflammatory pseudotumor, 1 neurofibroma, and 1 adenocarcinoma.

The 2 malignant lesions without specific diagnosis on needle biopsy were confirmed as Hodgkin's lymphoma by surgical biopsy and as metastatic osteosarcoma by clinical follow-up.

Utilizing surgical biopsy or clinical follow-up as a gold standard to calculate the sensitivity and specificity of needle biopsy for determining the presence of malignancy in a total of 36 cases, we obtained a sensitivity of $96.8 \%$, a specificity of $100 \%$, and an accuracy of $97.2 \%$ (Table 3 ).

In a total of 52 biopsies of lung lesions, complications occurred in 9 (17.3\%) - 4 after using an automated 18-gauge cutting needle (MD Tech TruCore) and 5 after using an automated coaxial 20-gauge cutting needle (Temno Biopsy needle and introductory cannula). Six cases (11.5\%) of small pneumothorax that did not require drainage, $1(1.9 \%)$ of hemoptysis, $1(1.9 \%)$ of

Table 1 - Results of core biopsy of 52 lung lesions.

\begin{tabular}{lcc}
\hline & No. Cases & Specific diagnosis \\
\hline Adequate sample & $51(98.1 \%)$ & \\
Benign & $9(17.3 \%)$ & $4(9.1 \%)$ \\
Malignant & $42(80.8 \%)$ & $40(90.9 \%)$ \\
\hline
\end{tabular}


Table 2 - Specific diagnosis of 51 core biopsies of lung lesions and definitive diagnoses of 36 cases confirmed by surgery or clinical follow-up.

\begin{tabular}{lccc}
\hline Diagnosis & Number of lesions & Definitive diagnoses & Confirmation criteria \\
\hline Malignant lesions & 42 & 31 & 25 clinically/6 surgery \\
Bronchogenic carcinomas & 26 & 18 & \\
Non-small cell & 20 & 16 & 13 clinically/3 surgery \\
Small cell & 2 & 2 & 2 clinically \\
Not specified & 4 & & \\
Metastatic disease & 11 & 9 & 5 clinically/1 surgery \\
Carcinoma & 9 & 6 & 3 clinically \\
Sarcoma & 2 & 3 & 1 clinically/2 surgery \\
Lymphoma & 2 & 3 & clinically \\
Mesothelioma & 1 & 1 & 2 clinically/3 surgery \\
Not specified & 2 & & No confirmation of diagnosis \\
Benign lesions & 9 & 5 & Radiological image resolution \\
Hamartoma & 1 & 0 & Radiological image \\
Chronic inflammation & 1 & 1 & stability for 2 years \\
Fibrosis & 2 & 1 & surgery \\
Granuloma (tuberculosis) & 0 & 1 & surgery \\
Inflammatory pseudotumor & 0 & 1 & surgery \\
Neurofibroma & 0 & 1 & \\
Not specified & 5 & &
\end{tabular}

Table 3 - Needle biopsy versus surgical/ clinical diagnosis.

Surgical or clinical diagnosis

Needle biopsy Malignant Benign Total

\begin{tabular}{lccc}
\hline Malignant & 30 & 0 & 30 \\
Benign & 1 & 5 & 6 \\
Total & 31 & 5 & 36 \\
\hline
\end{tabular}

pulmonary hematoma, and $1(1.9 \%)$ of thoracic wall hematoma were documented. All had spontaneous resolution. There were no complications requiring subsequent intervention.

\section{DISCUSSION}

Despite the popularity of automated systems for obtaining tissue samples in several solid organs ${ }^{3}$, their use in lung lesions has been very restricted in our country. Previous studies have demonstrated the advantage of the diagnostic yield of the cutting needle biopsy, with acceptable incidence of complications, when compared to fine-needle aspiration biopsy. Coaxial needles have the advantage of using a smaller gauge introductory cannula, allowing many passages of the cutting needle after its placement. In the present study, the supply of coaxial systems was not constant, and Tru-Core cutting needles were used as substitutes. Our study demonstrated that cutting needles, either with or without a coaxial system, provided appropriate pathology material $(98.1 \%)$ for histological analysis and diagnosis, with an accuracy of $97.2 \%$, a sensitivity of $96.8 \%$, and a specificity of $100 \%$ in identifying malignant lesions. These values are comparable to the results found in previous papers, with reported accuracy ranging from $80 \%$ to $95 \%{ }^{5-8}$, sensitivity from $93 \%$ to $95 \%{ }^{5-6,8}$, and specificity of $100 \%$ for malignant lesions ${ }^{6,8}$. The high rate of adequate samples (98.1\%) probably results from the use of automated systems that provide standardized collection of the material, which are less operator-dependent in comparison with fine-needle aspiration biopsies that supply appropriate samples varying from $16 \%$ to $94 \%$ of time ${ }^{6,9}$. The specific diagnosis rate $(84.6 \%)$ is also greater than reported in the literature for fine-needle aspiration biopsies (39\% to $77 \% \%^{4-5}$ ), eliminating the need for the presence of a cytopathologist during the biopsy procedure.

The number of complications was small (17.3\%), and all cases had good outcome, demonstrating the safety of the method. The incidence of pneumothorax reported in the literature varies from $9 \%$ to $54 \%$ for biopsies using automated systems ${ }^{5-7}$, which is similar to findings in our study (11.4\%). No chest tube placement was needed in our patients, while the rate of thoracic drainage varied from $2 \%$ to $18 \%$ in the previous studies ${ }^{5-6}$. This result could be explained by the selection of different types of needles for lesions with different sizes and locations. Although the distance analysis between the lesion and the thoracic wall was not possible for all cases, there was a trend, in agreement with the literature, of using 18 -gauge cutting needles for larger and more outlying lesions and 20-gauge needles with coaxial system for smaller and deeper lesions.

The high sensitivity and specificity of the method and low rate of complications have established the cutting needle biopsy as an efficient and safe tool for diagnosis of lung lesions. In our hospital, cutting needle biopsy is considered a reliable procedure for the evaluation of indeterminate pulmonary nodules. 
YU LS e col. - Biópsia de lesões pulmonares por agulha cortante guiada pela tomografia computadorizada. Rev. Hosp. Clín. Fac. Med. S. Paulo 57(1):15-18, 2002.

OBJETIVO: Apresentar a experiência inicial de um serviço de radiologia, no uso de biópsia de lesões pulmonares por agulha cortante guiada por tomografia computadorizada, avaliando o valor diagnóstico e incidência de complicações.

MÉTODOS: Realizamos análise retrospectiva de 52 pacientes submetidos à biópsia de lesão pulmonar guiada pela tomografia computadorizada. Analisamos o período de maio de 1997 até maio de 2000 . Trinta e cinco paci- entes eram de sexo masculino e $17 \mathrm{fe}$ minino, com idade variando de cinco a 85 anos (mediana de 62 anos). O tamanho das lesões pulmonares variou de 1,8 a $15 \mathrm{~cm}$ (mediana de $5,4 \mathrm{~cm}$ ).

RESULTADOS: Entre os 52 casos, $51(98,1 \%)$ forneceram material adequado para diagnóstico histopatológico, com nove diagnósticos $(17,3 \%)$ de lesão benigna e $42(80,8 \%)$ de lesão maligna. Quarenta e quatro $(84,6 \%)$ obtiveram diagnósticos específicos a partir de análise histopatológica, sendo quatro benignos e 40 malignos. A sensibilidade, a especificidade e a acurácia do método para lesões malignas foi de $96,8 \%$, $100 \%$ e $97,2 \%$, respectivamente. Nove casos $(17,3 \%)$ de complicações ocorreram, sendo seis casos $(11,5 \%)$ de pneumotórax pequeno, um $(1,9 \%)$ de hemoptise, um $(1,9 \%)$ de hematoma intrapulmonar e um outro caso $(1,9 \%)$ de hematoma na parede torácica. Não houve complicação que necessitasse de intervenção posterior.

CONCLUSÃO: As altas sensibilidade e especificidade, e o baixo índice de complicações tornam o método de biópsia por agulhas cortantes uma ferramenta eficiente e segura para diagnóstico de lesões pulmonares. Em nosso hospital é considerado um procedimento confiável para a avaliação de nódulos pulmonares indeterminados.

DESCRITORES: Neoplasia pulmonar. Tomografia computadorizada. Biópsia por agulha.

\section{REFERENCES}

1. AUSTIN JHM \& COHEN MB - Value of having a cytopathologist present during percutaneous fine-needle aspiration biopsy of lung: report of 55 cancer patients and meta-analysis of the literature. AJR 1993; 160:175-177.

2. KHOURI NF, STITIK FB, EROZAN YS et al. - Transthoracic needle aspiration biopsy of benign and malignant lung lesions. AJR 1985; 144:281-288.

3. MOULTON JS \& MOORE PT - Coaxial percutaneous biopsy technique with automated biopsy devices: value in improving accuracy and negative predictive value. Radiology 1993; 186:515522.

4. STANLEY JH, FISH GD, ADRIOLE JG et al. - Lung lesions: cytologic diagnosis by fine-needle biopsy. Radiology 1993; 186:515-522.

5. KLEIN JS, SALOMON G \& STEWART EA - Transthoracic needle biopsy with a coaxial placed 20-gauge automated cutting needle: results in 122 patients. Radiology 1996; 198(3):715-720.
6. LUCIDARME O, FINET JF, GRENIER PA et al. - Intrapulmonary lesions: percutaneous automated biopsy with a detachable, 18gauge, coaxial cutting needle. Radiology 1998; 207(3):759-765.

7. HARAMATI LB - CT-guided automated needle biopsy of the chest. AJR Am J Roentgenol 1995; 165(1):53-55.

8. WESTCOTT JL, RAO N \& COLLEY DP - Transthoracic needle biopsy of small pulmonary nodules. Radiology 1997; 202(1):97103.

9. SANTOS GC, CHOJNIAK R, LONGATTO FILHO A et al. - Fine needle aspiration of thoracic lesions: Experience in a Brazilian cancer center. Pathologica 1999; 91:256-259.

10. JUNQUEIRA MAF, FILHO MT, VARGAS FS et al. - Biópsia pulmonar transtorácica orientada por tomografia computadorizada. J Pneumol 1990; 16:1-5.

Received for publication on March 20, 2001. 